\title{
Prevalence and Characteristics of Hepatitis B Virus in HIV Infected Patients in North India
}

\author{
Parul Punia*, Anita Chakravarti, Anjar Ashraf, Richa Dewan and Preena Bhalla \\ PGIMS Rohtak, India \\ *Corresponding author
}

A B S T R A C T

Keywords

$\mathrm{HBV}, \mathrm{HBs} \mathrm{Ag}, \mathrm{HBe}$

$\mathrm{Ag}$, Total anti $\mathrm{HBc}$

$\mathrm{Ab}$, Anti HBs Ab,

HIV, CD-4, Co

infection.

Article Info

Accepted:

23 August 2017

Available Online:

10 September 2017
To study the epidemiology of HBV and HCV infection in HIV infected patients using various markers of $\mathrm{HBV}$ and $\mathrm{HCV} .70 \mathrm{HIV}$ positive ART naïve patients and 70 HIV negative controls were included in the study. Their samples were retrospectively analyzed for various markers of $\mathrm{HBV}$ infection like $\mathrm{HBs} \mathrm{Ag}, \mathrm{HBe}$ $\mathrm{Ag}$, total anti $\mathrm{HBc} \mathrm{Ab}$ and Anti HBs Ab. The co infection of HBV with HIV was observed in $14.28 \%$ cases, compared to $2.85 \%$ individuals in the control group with $\mathrm{HBV}$ infection defined on the basis of $\mathrm{HBs} \mathrm{Ag}$ positivity. HBV infection was found more prevalent in patients with CD-4 count $<350$ cells/ul. A higher prevalence of $\mathrm{HBe} \mathrm{Ag}$ positive disease was observed in HIV infected individuals. $\mathrm{HBV}$ as well as HCV infection is more prevalent in HIV infected individuals as compared to HIV non infected individuals. Also, a higher rate of HBV infectivity was observed in HIV infected patients.

\section{Introduction}

Until recently, opportunistic infections human immunodeficiency virus (HIV) infection overshadowed coexisting conditions such as hepatitis B virus (HBV), as a consequence of which clinicians were tepid about the cognizance of HIV-HBV co infection. Since the introduction of anti-retro viral therapy (ART), life expectancy of HIV infected individuals has improved, resulting in upsurge of comorbid conditions like $\mathrm{HBV}$, which share a similar route of transmission with HIV.

The prevalence of HIV-HBV co infection varies within different geographical areas in the world ranging from $9-30 \%{ }^{1}$
In HIV infected patients, there is higher rate of HBV chronic carriage, enhanced HBV replication with these problems further accentuated by complications in management.

A theoretical effect of HBV in enhancing HIV replication, leading to a more rapid reduction in CD4 cell counts in co infected patients has been described but there is little evidence to substantiate this. ${ }^{2}$

All this has lent a sense of urgency for formulating a pragmatic approach to address this invincible problem and hence this study has been undertaken. 


\section{Materials and Methods}

A cross sectional study was conducted on individuals in the age group 18-49 years attending Integrated Counseling and Testing Center (ICTC), Maulana Azad Medical College and associated Lok Nayak Hospital, New Delhi. 70 ART naïve HIV infected individuals were included as cases along with $70 \mathrm{HIV}$ non infected "high risk" individuals as controls.

Three rapid tests were used to detect HIV-1 and 2 antibodies as per strategy 3 of NACO guidelines for detection of HIV infection. Immunological status was assessed by determining the absolute CD-4 T lymphocyte count by FACS Count ${ }^{\mathrm{TM}}$ (Becton Dickinson). The HIV infected individuals were staged clinically in accordance with the WHO guidelines $^{3}$.

For the diagnosis of HBV infection, serological markers tested were $\mathrm{HBs} \mathrm{Ag}, \mathrm{HBe}$ $\mathrm{Ag}$, Total anti $\mathrm{HBc} \mathrm{Ab}$, Anti HBs Abusing commercially available ELISA kits.

\section{Results and Discussion}

Mean age of the study population was 33.82 years and male gender predominance (62.85\%) was observed. Amongst the 70 HIV infected individuals, HBV/ HIV co infection was seen in 10 (14.28\%) cases, compared to 2 $(2.85 \%)$ individuals in the control group. HBV infection was defined on the basis of HBs Ag positivity. In a total of 10 co infected cases, there were $8(18.18 \%)$ males against 2 (8.0\%) females. Co infection was detected most commonly in the age group 20-30years (50\%) followed by $31-40$ years $(30 \%)$. Of the 70 HIV infected cases, there were 15 cases $(21.42 \%)$ that were alone positive for total anti $\mathrm{HBc} \mathrm{Ab}$ in contrast to only $3(4.28 \%$ ) in the control group. $\mathrm{HBe} \mathrm{Ag}$ was detected in 6 $(60 \%)$ out of 10 co infected cases, whereas none of the $\mathrm{HBs} \mathrm{Ag}$ positive individuals in the HIV negative group had $\mathrm{HBe} \mathrm{Ag}$ positive. Anti HBs antibody was detected in 9 (12.85\%) HIV infected individuals compared to $18(25.71 \%)$ in the control group (Table 1$)$. Out of the 10 co infected cases, there were 7 HBs Ag positive cases with CD-4 count less than 350 cells/ul with $71.42 \%$ cases out of them reactive for $\mathrm{HBe} \mathrm{Ag}$. Out of the HIV/HBV co infected cases with CD-4 > 350 cells/ul $33.33 \%$ were reactive for $\mathrm{HBe} \mathrm{Ag}$ as shown in Graph 1.

Maximum prevalence of $\mathrm{HBV}$ positive cases were found in WHO clinical stage 4.No statistically significant difference was observed between $\mathrm{HBe} \mathrm{Ag}$ reactivity and WHO clinical stage. The predominant risk factor associated with co infection was heterosexual behavior $(60 \%)$ followed by MSM (30\%) and IVD abuse (10\%). $80 \%$ of the co infected cases had aspartate transferases (AST) levels > $40 \mathrm{IU} / \mathrm{ml}$.

The associated complications and the queer nature of serological findings prevalent in the subjects' co infected with HIV-HBV co infection instigated this regional surveillance.

The mean age and the male female ratio of our study group is representative of the national projection as stated by the "HIV sentinel surveillance and HIV estimation in India 2007 "report by NACO. ${ }^{4}$

We observed that HIV infected patients are at a higher risk of acquiring HBV infection compared to HIV negative individuals with males outnumbering females and the predominant age group being 20-30 yrs. Similar results have been observed in studies done elsewhere in India and abroad. ${ }^{1,5,6,7}$ The comparatively higher prevalence of $\mathrm{HBV}$ infection in our study could be due to the age group of 20-50 yrs which is the sexually active population. Heterosexual mode of 
transmission was observed to be the commonest mode of transmission as observed by other studies also. ${ }^{8}$

We found a fairly high prevalence of HBV infection in the HIV negative high risk group
(2.85\%) compared to a group of healthy individuals as controls included by other studies. ${ }^{5}$ This indicates that although HBV infection is more prevalent in HIV infected individuals but high risk behavior is an independent risk factor for HBV transmission.

\begin{tabular}{|c|c|c|}
\hline \multicolumn{3}{|c|}{ Table.1 HBV serological markers in the study group ( $\mathrm{n}=70)$} \\
\hline VIRAL MARKER & HIV positive individuals (\%) & HIV negative individuals (\%) \\
\hline HBs Ag & $10(14.28)$ & $2(2.85 \%)$ \\
\hline HBs Ag + HBe Ag & $6(8.57)$ & 0 \\
\hline Total Anti HBc Ab & $15(21.42)$ & $3(4.28 \%)$ \\
\hline Anti HBs Ab & $9(12.85)$ & $18(25.71 \%)$ \\
\hline
\end{tabular}

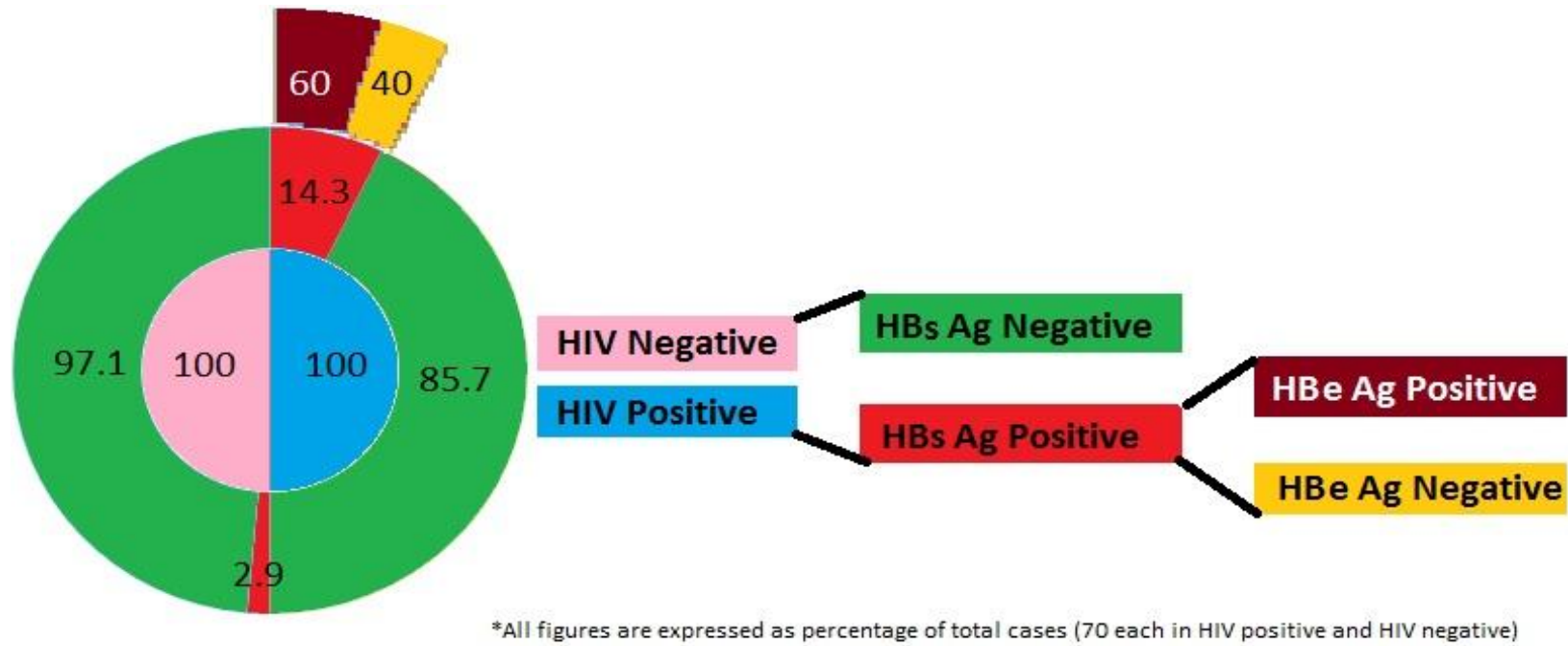

Another risk factor for HIV-HBV co infection is the immune status of the patient. In the present study, HBV infection was found more prevalent in patients with CD-4 count $<350$ cells/ul suggesting a high degree of immunodeficiency concurrent with a higher prevalence of $\mathrm{HBV}$ infection as transpired in other studies also. ${ }^{8}$

There are very few studies in India as well as abroad that included various markers like HBs Ag, HBe Ag, anti HBs Ab and total anti $\mathrm{HBc} \mathrm{Ab}$ for the characterization of $\mathrm{HBV}$ infection. Presence of isolated antibody to hepatitis B core antigen (anti-HBc) has been observed more often in HIV-infected patients because of impaired host immunity against
HBV. ${ }^{9}$ In our study also, we observed a high prevalence of total anti $\mathrm{HBc} \mathrm{Ab}$ alone in HIV infected group. Also, patients with antibodies to $\mathrm{HBV}$ core protein without $\mathrm{HBs} \mathrm{Ag}$ can have HBV DNA and occult HBV infection. So, HBV DNA should also be further tested for more accurate diagnosis.

$\mathrm{HBe} \mathrm{Ag}$ reactivity was observed in $60 \%$ of HIV infected individuals with not a single case with $\mathrm{HBe}$ Ag positivity among the HIV non infected $\mathrm{HBs} \mathrm{Ag}$ positive individuals. Probable explanation for this could be the reduced rate of spontaneous $\mathrm{HBe} \mathrm{Ag}$ sero conversion leading to a higher prevalence of $\mathrm{HBe}$ Ag positive disease in HIV infected individuals, the findings being supported by 
studies in India and abroad. ${ }^{10,11} \mathrm{We}$ also observed that the rate of infectivity ( $\mathrm{HBe} \mathrm{Ag}$ positivity) in HIV/HBV co-infected individuals is significantly higher in patients with CD-4 count $<350$ cells/ul emphasizing that the rate of HBV infectivity is directly proportional to immunosuppression. The prevalence of $\mathrm{HBV}$ infection was found in largest proportion in the WHO clinical stage 4 associating it with advanced HIV disease. No such correlation was found between $\mathrm{HBe} \mathrm{Ag}$ infectivity and WHO clinical staging. To the best of our knowledge, none of the studies have concluded this so far.

In studies done abroad ${ }^{11,12}$ there were $7 \%$ and $11.5 \%$ respectively of HIV infected individuals who were positive for anti HBs antibodies. The presence of isolated anti-HBs antibody in our study was detected in $12.85 \%$ of HIV infected patients as compared to $25.71 \%$ in individuals not infected with HIV. These patients with isolated anti-HBs may be considered as immunized against $\mathrm{HBV}$ or sero conversion after HBV infection, although a detailed history of immunization was not available. This lower percentage of anti HBs antibodies in HIV infected individuals emphasizes that these individuals have reduced capability and unpredictability of antibody production.

Since it was not feasible to do the liver biopsy which is a more specific means of assessing liver damage, we subjected the serum of all these patients to various biochemical tests. We found that the co infected patients were significantly associated with raised levels of AST compared to patients with only HIV infection suggesting a higher risk for hepatic complications, supported by studies done abroad. ${ }^{11,12}$

Thus it can be concluded that due to epidemiological similarities, HIV and HBV are inextricably linked and emphatically demand cognizance. Though we have yet to grapple with the problem of co infection but diligent efforts in diagnosing and making universal screening of these hepatitis viruses in HIV infected individuals mandatory, with inclusion of maximum number of $\mathrm{HBV}$ markers, we can hope to stifle the unrest in the lives of these patients.

\section{References}

Antiretroviral therapy for HIV infection in adults and adolescents: Recommendation for a public health approach. World Health Organization 2010 Revision cited 2010 January.

Fix, O.K., Locarnini SA and Peters MG. Virology and clinical management of Hepatitis B and HIV co-infection. [Online]. 2007 April; 11(4):20-7. Available from: http://www.prn.org.

Gupta, S., and Singh S. Hepatitis B and C virus co-infections in human immunodeficiency virus positive north Indian patients. World J Gastroenterol 2006; November; 12(42):6879-83.

HIV Sentinel Surveillance and HIV estimation in India 2007. A Technical Brief. [Online]. 2008 [cited 2009 Apr 22]; Available from: URL: http://www.nacoonline.org/upload/Publi cation/M\&E\%20Surveillance, \%20Rese arch/HIV\%20Sentinel\%20Surveillance $\% 20$ and $\% 20 \mathrm{HIV} \% 20$ Estimation\%2020 07_A\%20Technical\%20Brief.pdf

Jain, M., Chakravarti A, Verma V, Bhalla P. Seroprevalence of hepatitis viruses in patients infected with the human immunodeficiency virus. J Pathol and Microbiol 2009; 52(1):17-9

Mohammadi, M., Talei G, Sheikhian A, Ebrahimzade F, Pournia Y, Ghasemi E et al., Survey of both hepatitis B virus (HBsAg) and hepatitis $\mathrm{C}$ virus (HCVAb) co-infection among HIV positive patients. Virology Journal 2009; 6; 202. 
[Online]. Available from: Saravanan, S., Velu V, Kumarasamy N, http;//www.virology j.com/content/6/1/202.

Ockenga, J., Tillmann HL, Trautwein C, Stoll M, Manns MP and Schmidt RE. Hepatitis B and C in HIV-infected patients Prevalence and prognostic value. Journal of Hepatology 1997;27:18-24.

Otegbayo, J.A., Taiwo BO, Akingbola TS, Odaibo GN, Adedapo S, Penugonda S et al., Prevalence of hepatitis B and C seropositivity in a Nigerian cohort of HIV infected patients. Annals of Hepatology 2008; 7(2):152-6.

Reuter, S., Oette M, Wilhhelm FC, Beggel B, Kaiser R, Balduin M et al., Prevalence and characteristics of hepatitis $\mathrm{B}$ and $\mathrm{C}$ virus infections in treatment -naïve HIV-infected patients. Med Microbiol Immunol 2011;200;39-49.

Nandakumar S, Murugavel KG, Balakrishnan $\mathrm{P}$ et al., Coinfection of hepatitis B and hepatitis C virus in HIV infected patients in South India. World J Gastroenterol 2007;13:5015-20.

Sheng, W.H., Kao JH, Chen PJ, Huang LM, Chang SY, Sun H.Y, Hung CC, Chen MY and Chang SC. Evolution of Hepatitis B serological markers in HIVinfected patients receiving Highly Active Antiretroviral Therapy. J Clinical Infectious Diseases 2007; 45:1221-9.

Tripathi, A.K., Khanna M, Gupta N, Chandra M. Low prevalence of Hepatitis B virus and Hepatitis $\mathrm{C}$ virus Co-infection in Patients with Human Immunodeficiency Virus in Northern India 2007 June;55:429-31.

\section{How to cite this article:}

Parul Punia, Anita Chakravarti, Anjar Ashraf, Richa Dewan and Preena Bhalla. 2017. Prevalence and Characteristics of Hepatitis B Virus in HIV Infected Patients in North India. Int.J.Curr.Microbiol.App.Sci. 6(9): 2405-2409. doi: https://doi.org/10.20546/ijcmas.2017.609.295 